\title{
serie The determinants of net interest income in the Mexican banking system: an integrated model
}


Los documentos de trabajo del Ivie ofrecen un avance de los resultados de las investigaciones económicas en curso, con objeto de generar un proceso de discusión previo a su remisión a las revistas científicas. Al publicar este documento de trabajo, el Ivie no asume responsabilidad sobre su contenido.

Ivie working papers offer in advance the results of economic research under way in order to encourage a discussion process before sending them to scientific journals for their final publication. Ivie's decision to publish this working paper does not imply any responsibility for its content.

La Serie EC, coordinada por Matilde Mas, está orientada a la aplicación de distintos instrumentos de análisis al estudio de problemas económicos concretos.

Coordinated by Matilde Mas, the EC Series mainly includes applications of different analytical tools to the study of specific economic problems.

Todos los documentos de trabajo están disponibles de forma gratuita en la web del Ivie http://www.ivie.es, así como las instrucciones para los autores que desean publicar en nuestras series.

Working papers can be downloaded free of charge from the Ivie website http://www.ivie.es, as well as the instructions for authors who are interested in publishing in our series.

Edita / Published by: Instituto Valenciano de Investigaciones Económicas, S.A.

Depósito Legal / Legal Deposit no.: V-1684-2009

Impreso en España (abril 2009) / Printed in Spain (April 2009) 
WP-EC 2009-05

\title{
The determinants of net interest income in the Mexican banking system: an integrated model*
}

\author{
Joaquín Maudos and Liliana Solís ${ }^{* *}$
}

\begin{abstract}
This paper analyzes net interest income in the Mexican banking system over the period 19932005. Taking as reference the seminal work by Ho and Saunders (1981) and subsequent extensions by other authors, our study models the net interest margin simultaneously including operating costs and diversification and specialization as determinants of the margin. The results referring to the Mexican case show that its high margins can be explained mainly by average operating costs and by market power. Although non-interest income has increased in recent years, its economic impact is low.
\end{abstract}

JEL classification: G21, L10

Keywords: banking, net interest income, operating cost, non-interest income

\section{Resumen}

El trabajo analiza el margen de intermediación de la banca Mexicana en el periodo 1996-2005. Tomando como referencia el trabajo seminal de Ho and Saunders (1981) y extensiones posteriores de otros autores, nuestro estudio modeliza el margen de intermediación incluyendo simultáneamente los costes operativos y la diversificación y especialización como determinantes del margen. Los resultados referidos al caso mexicano muestran que los altos márgenes vienen explicados principalmente por los costes medios operativos y por el poder de mercado. Si bien los ingresos no financieros han aumentando en los últimos años, su impacto económico es reducido.

Palabras claves: banca, margen financiero, costes operativos, poder de mercado, Ingresos no financieros.

\footnotetext{
"The authors wish to thank the anonymous referees for their comments and suggestions and the financial support of the Valencian Institute of Economic Research (Ivie). Liliana Solís also thanks the Banco de México for the information provided and the National Council for Science and Technology (CONACYT) and Carolina Foundation for their financial support. The study has been carried out within the framework of the research programs of the Spanish Ministry of Education and Science -FEDER (SEJ2007-60320 and ECO2008-03813).

** J. Maudos: Universitat de València and Instituto Valenciano de Investigaciones Económicas (Ivie).

L. Solís: Universidad Complutense de Madrid. Corresponding author: joaquin.maudos@ivie.es,
} 


\section{Introduction}

One of the main functions of the financial system in general, and the banking system in particular, is to favor economic growth through efficient intermediation between the savings of depositors and the investment of those demanding finance. Given that the exercise of market power translates into high margins that act as a disincentive to both savings and investment, the banking sector must be both efficient and competitive.

This desirable situation of efficiency and competition does not correspond to the situation existing in many banking sectors, and particularly in the Mexican banking system. In relation to international standards, Mexico has high interest margins reflecting high intermediation costs, which in turn have a negative effect on the growth of savings, investment, employment and, consequently, the economic growth of the country. In this context, it is of great interest to analyze the determinants of the net interest margin, dedicating special attention to the importance of competition in banking markets.

The literature on banking has developed various models over the years explaining the behavior of the intermediation margin, and showing the importance of factors such as the degree of competition, credit risk, market risk, average operating costs, etc. In particular, the seminal study by Ho and Saunders (1981) models a bank as an intermediary between lenders and borrowers, and shows that the optimal pure spread depends on four factors: the degree of risk aversion, the market structure (proxy for competition), the average size of bank transactions, and the variance of the interest rate on loans and deposits (market risk).

Subsequently, the theoretical model by Ho and Saunders (1981) has been expanded by other authors: Allen (1988) considers various types of loans with interdependent demands; Angbazo (1997) incorporates credit risk and interest rate risk, as well as the interaction between these two types of risk; Maudos and Fernández de Guevara (2004) include average operating costs as a determinant of the intermediation margin and use the Lerner index of market power as a direct measurement of the degree of competition; Carbó and Rodríguez (2007) extend the model by incorporating the importance of "non-traditional" activities, proposing a multi-output model with the aim of analyzing the relationship between bank margins and specialization. The model by Ho and Saunders (1981) has also been estimated empirically for the U.S. banking system and for six European countries by Saunders and Schumacher (2000); the 
European banking system has also been analyzed by Lepetit et al. (2008); and Latin American banking by Brock and Rojas (2000), Martínez and Mody (2004), and Gelos (2006).

In this context, the model of the determinants of the intermediation margin has not been estimated for the specific case of the Mexican banking system, and constitutes an interesting sector of analysis given that it has undergone continual structural changes in recent years ${ }^{1}$ : liberalization of the sector through deregulation of interest rates, the abolition of coefficients of selective assignation of credit, and the elimination of the system of legal coefficients (1988-89). Subsequently, between 1991 and 1992, the banks were re-privatized after being nationalized in 1982 and a gradual opening-up of this sector to foreign investment began with the North American Free Trade Agreement (NAFTA). There was also a sharp increase in private credit without effective risk control, thus causing deterioration in banking assets. The conditions of this sector worsened with the financial and exchange rate collapse of 1994-95, which forced the Government to implement measures aimed at combating the high insolvency of the banks. Among them was the acceleration of the process of gradual opening-up to foreign investment (to inject capital) which, following the mergers and acquisitions that took place, led to the consolidation of this industry.

There are several reasons which can explain the relevance and "uniqueness" of the Mexican case: a) it is a banking system which, over the period analyzed, has been subject to important structural changes. The events described above were accompanied by substantial changes in the banking regulation; b) the income structure of the Mexican banking system has changed as the non-interest income has become more important; c) the majority of the papers have analyzed empirically the determinants of interest margins in developed countries, whereas the Mexican case is characterized by a low level of bancarization (measured by bank's assets to GDP); 4) the evolution of the net interest margin and the macroeconomic (and financial) conditions have been quite unstable during the last two decades, making Mexico a good laboratory in which to analyze the relationships between these two variables; and 5) given that the interest margin still remains at a high level, it is essential to analyze what causes this. Among the reasons usually given is the low level of competition, where there is evidence that monopolistic practices exist in some important markets (Avalos and Hernández-Trillo, 2006). It is therefore of great interest to explore how competition affects the evolution of banking margins. The model estimated serves to explain and quantify the importance

\footnotetext{
${ }^{1}$ See Hernández-Murillo (2007).
} 
of these (income structure, macroeconomic conditions, etc.), and other variables on the evolution of the interest net interest margin in Mexico. Given the importance of analyzing how the measures implemented have affected the evolution of Mexican banks' margins, the objectives and novelties of the paper are as follows. First, it models theoretically the determinants of the intermediation margin, incorporating both the seminal study by Ho and Saunders (1981) and subsequent individual contributions, which include both average operating costs and non-traditional activities as determinants of the intermediation margin (Allen, 1988; Angbazo, 1997; Maudos and Fernández de Guevara, 2004; Carbó and Rodríguez, 2007). Second, our study estimates for the first time the determinants of Mexican banks' net interest income and their economic impact over the period 1993-2005, a period of deregulation, liberalization and consolidation of the sector. Third, in line with the assumptions of Carbó and Rodríguez (2007) that banks need to match the random deposit supply function and the random demand for lending and non-traditional activities across periods, we estimate a dynamic model in order to capture the inertia in the evolution of banking margins. Finally, we analyze whether the growing importance of non-financial activities ${ }^{2}$ has caused a reduction of the net interest margin, as has occurred in developed countries.

The results obtained indicate that the greatest economic impact on the net interest margin is determined by operating costs and market power. The results also show that, in general, the expected signs are obtained in the coefficients of the variables considered in the literature explaining the intermediation margin. Thus, we find a positive relationship between the intermediation margin in the Mexican banking system and variables proxying market power (Lerner index), operating cost, volatility of market interest rates, implicit interest payment; and a negative relationship with the quality of management and non-interest income. This last negative effect may reflect a strategy of cross-subsidization with traditional activities in line with the findings of Carbó and Rodríguez (2007) and Lepetit et al. (2008). In other words, since banks engage in different non-lending activities, these other activities may influence the pricing of loan products due to cross-subsidization of bank products. However, its economic impact is insignificant.

The model estimated serves to explain the evolution of net interest income in Mexico. The decreasing trend of the margin up to 1996 is compatible with the increase of credit risk and the volatility of market interest rates given that the effect of these

\footnotetext{
${ }^{2}$ Specifically, net banking commissions represented $0.5 \%$ in 1993 of total assets, increasing to $1.1 \%$ in 1995 , to $1.5 \%$ in 2001 and to $2.0 \%$ in 2005 .
} 
variables is counteracted by the fall in market power and in operating costs. Subsequently, the margin presents an increasing trend until 1999 as a consequence of the increase in the Lerner index and in operating costs. The margin decreases from 2000 to 2003. This effect is explained by the fall in 2000 and 2001 (2002 and 2003) of average operating cost (market power), credit risk, and implicit interest payments which counteract the increase in market power (average operating costs). Finally, in the last two years of the period analyzed, market power increased which caused a rise in the intermediation margin.

From a financial stability perspective, the reasons behind the margin evolution in Mexico predominantly emanate from the micro level. Therefore, one of the main implications of economic policy deriving from the results obtained is the need to implement measures which are aimed at increasing competition and efficiency in the Mexican banking system, given the high economic impact of market power and of the average margin costs. In the first case, the evidence contributed by other works (Avalos and Hernández-Trillo, 2006; Solís and Maudos, 2008) shows that monopolistic practices exist in some important markets. Thus, it is necessary to prioritize measures aimed at increasing competition (such as decreasing the legal barriers to some products and fostering coordination between anti-trust authorities and regulators). In the second case, it is important that the Mexican banking system increases its levels of efficiency in costs, which will lower margins and benefit consumers.

In the current context of the international financial crisis, results from the study allow us to shed light on some of the possible effects on banking margins. The Mexican banking system is one of the sectors of the economy which has most suffered because of the successive crises that the country has gone through over the years (such as in 1995). The deterioration of macroeconomic conditions with the consequent increase in bad loans can pressure bank margins to rise caused by the greater risk premiums that banks will demand.

The structure of the rest of the paper is as follows. Section 2 reviews the literature that analyzes the determinants of the intermediation margins. Section 3 models the intermediation margin integrating into a single model the various extensions made to the original model by Ho and Saunders (1981). Section 4 specifies the sample used and presents the empirical results. Finally, section 5 concludes. 


\section{Literature review}

The initial study on the determinants of bank interest margins by Ho and Saunders (1981) modeled the behavior of a bank that acts as intermediary between lenders and borrowers. The theoretical model indicates that the optimum bank interest margin depends on four factors: the degree of risk aversion, the market structure, the average size of bank transactions and the variance of the interest rate on loans and deposits. Ho and Saunders empirically estimate the model for the U.S. banks, using a two step approach. In the first step, they estimate a regression of the individual bank's interest margin against bank-specific variables (implicit interest rate, opportunity cost of reserves, default premium) i.e. against variables that are not determined in the theoretical model. The constant term of this regression represents an estimate of the "pure spread" component for the banks, i.e. the portion of the margin that cannot be explained by bank-specific characteristics. In the second stage, they estimate a regression of the "pure spread" as a function of the volatility of interest rates. The constant term captures the effect of market structure on the determination of the "pure spread", and the coefficient of the explanatory variable measures the sensitivity of "pure spread" to variations in the volatility of interest rates for a number of maturities.

The original model by Ho and Saunders (1981) has been extended theoretically and estimated empirically by other authors. Thus, Allen (1988) extends it for various types of loans with interdependent demands and concludes that pure interest spreads may be reduced when cross-elasticities of demand between bank products are considered. Angbazo (1997) introduces credit risk and interest rate risk into the theoretical model, as well as the interaction between these two types of risk, and estimates it for U.S. commercial banks in 1989-93. Subsequently, the model is estimated empirically using a two step process by Saunders and Schumacher (2000) for the U.S. banking system and six European countries in 1988-95, and by Brock and Rojas (2000) for five Latin American countries (Argentina, Bolivia, Colombia, Chile and Peru).

Maudos and Fernández de Guevara (2004) make an interesting recent contribution. They expand the theoretical model by considering the importance of operating costs as a determinant of net interest income, and estimate it empirically for the main European banking sectors in the period 1992-2000. Furthermore, they use direct measurements of market power (Lerner index) instead of structural indicators of competition (market concentration indicators). The authors conclude that the increase in the Lerner index in European banks had a positive effect on the interest margin. This 
effect, however, was counteracted by the fall in operating costs, credit risk and implicit interest of payments, as well as the lower volatility of market interest rates. The authors find therefore that a situation of lower intermediation margins is compatible with increases in market power. The same expanded model by Maudos and Fernández de Guevara (2004) is estimated for the Spanish banking system for the period 1992-99 by Fernández de Guevara (2004).

Martínez and Mody (2004) study the impact of foreign participation and concentration on Latin American bank spreads (Argentina, Chile, Colombia, Mexico and Peru) and find that foreign banks are able to charge lower spreads and have lower costs than domestic banks. Moreover, those foreign banks that acquired domestic institutions have higher spreads than those that established de novo operations. On the other hand, the degree of concentration in the banking system has a positive and economically significant impact on both spreads. Gelos (2006) explains the differences between the levels of spread in Latin American banking systems and other emerging economies by analyzing the determinants of bank interest margins in a sample of 85 countries, including 14 Latin American economies. The author concludes that, in comparison to other emerging economies, spreads in Latin American banking markets are higher because of less efficient banks (weaker competition), relatively higher levels of interest rates and higher reserve requirements.

Another important contribution is that by Carbó and Rodríguez (2007). The authors develop the theoretical model by including both traditional and non-traditional activities, with the aim of studying the effect of specialization on bank margins using a multi-output model for European banking. In order to do this, they estimate a dynamic model, considering that banks need to match the random deposit supply function and the random demand of lending and non-traditional activities across periods. Their results show that diversification in non-traditional activities causes an increase in market power, and a decrease in spread as a consequence of cross-subsidization.

Another study that analyzes empirically the implications for bank interest margins of the expansion into non-traditional fee-based activities is Lepetit et al. (2008). These authors test for a possible cross-selling behavior of interest and noninterest products by analyzing the determinants of the risk premium charged by banks on their loans for the European banking system (1996-2002). 


\section{Methodology}

\subsection{An integrated model of the net interest margin}

The seminal model by Ho and Saunders (1981) has been extended in later studies by incorporating different factors to explain the net interest margin (Allen, 1988, Angbazo, 1997; Maudos and Fernández de Guevara, 2004; Carbó and Rodríguez, 2007). However, until now all the individual contributions have not been integrated into a single model. This section therefore aims to construct a complete integrated model of the determinants of net interest income simultaneously including operating costs, and diversification and specialization variables.

The essence of the model is to consider that the representative bank is a riskaverse agent that acts as intermediary between suppliers of deposits, and demanders of loans and non-interest outputs. The bank is also maximizer of its expected utility of terminal wealth in a single period. The bank faces the risk that there will be changes in interest rates in the money market and the uncertainty of the return on net credit. It therefore sets the interest rates (deposits $r_{D}$, loans $r_{L}$ and non-traditional outputs $r_{N}$ ) as a margin over the money market interest rate $(r)$ in order to cover itself against these risks. The planning horizon is a single period, and it is assumed that the banks set interest rates before transactions are entered into and that they remain constant until the end of the period. It is also assumed that the size of transactions in loans, deposits and non-traditional output is a fixed constant $Q$ (see Ho and Saunders, 1981).

Based on the multi-product framework by Carbó and Rodriguez (2007), the interest margin will be equal to $a+b_{L}$ (the immediacy fees for providing deposits and loans, respectively) and the gross margin will be $a+b_{L}+b_{N}$ (where $b_{N}$ is the fee charged for non-traditional activities). If we assume, as Maudos and Fernández de Guevera (2004) do, that operating costs $(C)$ are a function of the traditional and non-traditional activities, the first order conditions of the maximization problem yield the optimum intermediation margin (see the appendix):

$$
\begin{aligned}
a+b_{L}= & \frac{1}{2}\left(\frac{\alpha_{D}}{\beta_{D}}+\frac{\alpha_{L}}{\beta_{L}}\right)+\frac{C(D)+C(L)}{2 Q}+\frac{R Q}{2}\left[\sigma_{I}^{2}+\sigma_{M}^{2}-2 \sigma_{I M}\right] \\
& +\frac{\delta_{L}}{4 \beta_{L}}\left\{2 b_{N}\left(1+\frac{\delta_{N}}{\delta_{L}}\right)-R Y-\frac{2 C(N)}{Q}\right\}
\end{aligned}
$$


where $\alpha / \beta$ (proxy for market power) is the ratio of the intercept $(\alpha)$ and the slope $(\beta)$ of the deposit and loan arrival functions of the bank, $Q$ is the output transaction size, $R \equiv-U^{\prime \prime} / U^{\prime}$ is the coefficient of absolute risk aversion $\left(U^{\prime}>0\right.$ and $\left.U^{\prime}<0\right), \sigma_{I}^{2}$ is the variance of shochastic output inventory (which captures the uncertainty of the returns on net credit), $\sigma^{2}{ }_{M}$ is the volatility in the money market interest rate, $\sigma_{I M}$ is the covariance between credit risk and market risk, $\delta_{L}$ and $\delta_{N}$ are the cross-elasticities of demand across bank loans and non-traditional activities, and

$$
Y=\left(Q+2 I_{0}\right) \sigma_{I}^{2}+\left(Q-2 M_{0}\right) \sigma_{M}^{2}+2\left(M_{0}-I_{0}-Q\right) \sigma_{I M}
$$

In the case of the optimal gross margin $a+b_{L}+b_{N}$ :

$$
\begin{aligned}
a+b_{L}+ & b_{N}=\frac{1}{2}\left(\frac{\alpha_{D}}{\beta_{D}}+\frac{\alpha_{L}}{\beta_{L}}+\frac{\alpha_{N}}{\beta_{N}}\right)+\frac{C(D)+C(L)+C(N)}{2 Q}+\frac{R Q}{4}\left[\left(3 Q+2 I_{0}\right) \sigma_{I}^{2}\right. \\
& \left.+\left(3 Q-2 M_{0}\right) \sigma_{M}^{2}+2\left(M_{0}-I_{0}-3 Q\right) \sigma_{I M}\right] \\
& +\frac{\delta_{L}}{4 \beta_{L}}\left\{2\left(\frac{b_{L} \beta_{L}}{\beta_{N}}+b_{N}\right)\left(1+\frac{\delta_{N}}{\delta_{L}}\right)-R Y\left(1+\frac{\delta_{N} \beta_{L}}{\delta_{L} \beta_{N}}\right)\right\}-\frac{1}{2 Q}\left(\frac{\delta_{L} C(N)}{\beta_{L}}+\frac{\delta_{N} C(L)}{\beta_{N}}\right) \\
& \text { If } 2 b_{N}\left(1+\frac{\delta_{N}}{\delta_{L}}\right)-R Y-\frac{2 C(N)}{Q}<0, \text { i.e. } 2 b_{N}\left(1+\frac{\delta_{N}}{\delta_{L}}\right)<R Y+\frac{2 C(N)}{Q},
\end{aligned}
$$

the introduction of non-traditional activities reduces interest margin. Observe that when non-traditional activities are included, the margin is modified with the effect of market power, operating costs, the cross elasticities of demand across bank loans and nontraditional output, as well as by credit and market risks.

In addition to the variables posited by the theoretical model as determinants of pure spread, the empirical evidence shows that other variables also affect the net interest margin and must therefore be included in the empirical estimation of the model. Taking previous studies as reference, the following variables are used:

a) Implicit interest payment represents extra payments to depositors through services charge remission or other types of transfers. As this variable represents an additional expense, the bank will set a higher margin, so a positive relationship is expected (Ho and Saunders, 1981; Angbazo, 1997; Saunders and Schumacher, 2000; Maudos and Fernández de Guevara, 2004). 
b) The opportunity cost of keeping reserves: this represents an opportunity cost to the banks of not maintaining high-yielding assets, so the banks with high levels of reserves pass this cost on to borrowers by means of a high intermediation margin (Ho and Saunders, 1981; Angbazo, 1997; Saunders and Schumacher, 2000; Maudos and Fernández de Guevara, 2004).

c) The quality of management. Because banks which are inefficient in their management select less profitable assets and high-cost liabilities, their intermediation margins are therefore lower (Angbazo, 1997; Maudos and Fernández de Guevara, 2004).

d) Following Carbó and Rodríguez (2007), we consider specialization variables. Banks specializing in typical products of banking intermediation (loans and deposits) obtain reduced intermediation costs due to the existence of economies of scale, which translates into lower margins.

Additionally, and with the aim of controlling for the possible effect of macroeconomic conditions on the evolution of the intermediation margin, the following variables are frequently introduced:

e) GDP growth. The sign is not determined a priori. On the one hand, some studies show that margins are pro-cycle (Drakos, 2002; Claeys and Vander Vennet, 2007), while in others the margin is counter-cycle (Martínez and Mody, 2004; Gelos, 2006; Carbó and Rodríguez, 2007; Claeys and Vander Vennet, 2007).

f) Inflation rate. The sign is not determined a priori. Thus, some authors show that high inflation rates have an adverse effect on loan interest rates and this increase is reflected in higher intermediation margins (Demirgüç-Kunt and Huizinga, 1999; Brock and Rojas, 2000; Martinez and Mody, 2004; Claeys and Vander Vennet, 2008). However, there is the possibility that the interest rates on liabilities may adjust to an inflationary shock more quickly than those on assets, so there will be a negative relationship between inflation and the intermediation margin (Claeys and Vander Vennet, 2008).

\subsection{Econometric model}

In this section, we describe the empirical approximation of the determinants of intermediation margins in the Mexican banking system. We estimate a regression model of the net interest income $(M)$ (calculated as the difference between financial income 
and financial costs divided by total assets) as a function of pure spread (PS), bankspecific variables $(B S)$ and macroeconomic variables $(M E)$.

The model to be estimated is as follows:

$$
M_{i t}=\alpha_{i}+\sum_{j=1}^{J} \beta^{j} P S_{i t}^{j}+\sum_{k=1}^{K} \gamma^{k} B S_{i t}^{k}+\sum_{l=1}^{L} \delta^{l} M E_{t}+\varepsilon_{i t}
$$

for $t=1, \ldots, T$, where $T$ is the number of periods observed and $i=1, \ldots, I$, and $I$ is the total number of banks. Therefore, subscripts $i$ and $t$ refer to bank $i$ at time $t$, respectively. Pure spreads are the variables that theoretically determine the margin.

The variables are proxied empirically as follows:

a) Market power $(\alpha / \beta)$. We use the Lerner index for total banking activity (Lerner) and calculate it as the difference between the price and the total marginal cost (operating + financial) as a proportion of the price ${ }^{3}$. The price is proxied as the ratio of banking revenue ${ }^{4}$ and total assets; marginal costs are estimated from a translog total cost function with one output (total assets) and 3 inputs (labor, physical capital and lendable funds):

$$
\begin{aligned}
\ln T C_{i t}= & \alpha_{0}+\alpha_{j} \sum_{j=1}^{3} w_{i t}^{j}+\frac{1}{2} \sum_{j=1}^{3} \sum_{k=1}^{3} \alpha_{j k} \ln w_{i t}^{j} w_{i t}^{k}+\beta_{1} \ln Y_{i t}+\frac{1}{2} \beta_{2}\left(\ln Y_{i t}\right)^{2} \\
& +\sum_{j=1}^{3} \beta_{3 j} \ln Y_{i t} \ln w_{i t}^{j}+\gamma_{1 t} T+\frac{1}{2} \gamma_{2 t} T^{2}+\sum_{j=1}^{3} \gamma_{3 t} T \ln w_{i t}^{j} \\
& +\gamma_{4 t} T \ln Y_{i t}+\mu_{i}+u_{i}
\end{aligned}
$$

where $T C$ is the total costs, $w$ is the price of the 3 inputs [labor (personnel expenditure/ number of workers), lendable funds (financial costs/deposits) and capital (operating expenses other than personnel costs/fixed assets)], $Y$ is total assets, $T$ is a trend that captures the effect of technical progress and $\mu$ the individual fixed effects. The restrictions of symmetry and grade one homogeneity in input prices are imposed in the estimation.

\footnotetext{
${ }^{3}$ Since we have only national indicators available, which have a common value for all the banks of the sample, we cannot analyze the sensitivity of the results using market structure indicators.

4 The analysis is conducted with financial income. If total income is considered robust, results are obtained. However, the economic impact of market power and average operating costs are greater.
} 
A positive relationship between the Lerner index and the intermediation margin is expected, reflecting the fact that the banks with greater market power set a wider spread than they would in a competitive situation.

b) Following Maudos and Fernández de Guevara (2004) and Fernández de Guevara (2004), operating costs $(C)$ are measured by the ratio of operating expenses to total assets.

c) Credit risk $\left(\sigma_{I}^{2}\right)$ is proxied by the quotient of loan loss provisions over loans (Angbazo, 1997).

d) Following McShane and Sharpe (1985) and Maudos and Fernández de Guevara (2004), the degree of risk aversion $(R)$ is proxied by the ratio of equity to total assets $^{5}$.

e) Market risk $\left(\sigma^{2}{ }_{M}\right)$ is proxied by the annual standard deviation of weekly real interest rates on Federation Treasury Certificates (CETES) at 91 days (SD91) (Saunders and Schumacher, 2000). Because this variable does not present variability between banks, it only varies over time.

f) Interaction between credit risk and market risk $\left(\sigma_{I M}\right)$ is calculated as the product of non-performing loans/loans and market risk. Since (loan loss provisions/loans)*SD91 presents multicollinearity with SD91, non-performing loans/loans is used as proxy for credit risk.

g) Transaction size $(Q=$ size $)$. Although we do not have information to proxy the transactions made, we include the logarithm of loans as proxy of size, as suggested by Maudos and Fernández de Guevara (2004).

h) Net non-interest income (nii) is calculated as the ratio of net non-interest income (non-interest income minus non-interest expenses) as a percentage of total assets $^{6}$. A diversified bank is expected be able to offer its traditional products with very small and even negative margins (with the aim of attracting or keeping clients), and

\footnotetext{
${ }^{5}$ A better proxy of this variable would be the capital held in excess of regulatory capital. However, this variable is not available. Since the variable used is a measure of capitalization, the results are influenced by regulation on minimum equity.

${ }^{6}$ Initially, this variable was estimated in terms of net operating income (Lepetit et al., 2008). However, it presents collinearity with the efficiency of banking management. This problem is avoided by redefining the variable in terms of total assets.
} 
recuperates this loss by setting higher fees. Its income from non-interest activities therefore increases, reflecting a cross-subsidization strategy ${ }^{7}$.

i) Income from fees and commissions (fee) is proxied by net fee income/total assets. Its expected sign is negative.

j) Income from trading (trade) represents profits and losses generated by buying and selling securities and currencies, as well as the revaluation of banks' positions in securities. It is proxied by nii minus fee.

As mentioned above, although not considered explicitly in the theoretical model, there are other variables which influence margins. Using previous studies as reference, the variables are proxied as follows:

k) Implicit Interest Payments are obtained as the difference between non interest expense and other operating income in terms of total assets ${ }^{8}$.

1) The opportunity cost of holding reserves is estimated by the ratio of liquid reserves (proxied by cash variable) to total assets.

m) The quality of management (Efficiency) is proxied by the cost to gross income ratio. Because high levels of operating cost per unit of gross income reflect banks that are not efficient in their management, they select less profitable assets and high-cost liabilities. Thus, a negative sign is expected.

n) The loans/total assets and deposits/total assets ratios are considered to be specialization variables.

Finally, as macroeconomic variables:

o) GDP growth $(G D P)$ in constant 1993 Mexican pesos.

p) Inflation rate (inflation). Growth rate of the consumer price index (annual inflation rate).

\footnotetext{
${ }^{7}$ Banks usually have different product mixes, which may influence the pricing of loan products. Therefore, banks with well-developed non-interest income sources may have lower interest margins due to cross-subsidization of bank activities.

${ }^{8}$ To begin with, this variable was estimated in terms of net operating income. However, it presents collinearity with operating costs. To avoid this problem, it is redefined by changing the scale.
} 


\section{Sample and results}

The sample used is formed by an unbalanced panel of data from 289 annual observations, corresponding to 43 commercial banks for the period between 1993 and 2005 , which represent an average of $92 \%$ of the total assets in the Mexican commercial banking system during the period of study ${ }^{9}$. The data are obtained from the Statistical Bulletin of the Multiple Banking system of the National Banking and Securities Commission (known by its Spanish acronym CNBV), and from the Basic Banking Information System of the Bank of Mexico. Table 1 shows the descriptive statistics of the net interest margins and their determinants, as well as the number of observations in each year.

Equation (2) is estimated with fixed effects in order to capture the influence of specific variables of each bank. Temporal effects are not included because they present multicollinearity with the volatility of the market interest rate.

The results of the different estimations are presented in table 2. First, the most general case is estimated (column 1). Next, the diversification variables are included, in the aggregate and disaggregated (columns 2, 4 and 3, 5, respectively). Finally, specialization variables are included (columns 4 and 5). In general, the expected signs are obtained in the coefficients of the variables considered in the literature. In the case of the variables that capture the influence of macroeconomic conditions (GDP, inflation), they are not reported in the tables as they are not statistically significant.

In all cases, the signs of the coefficients of the Lerner index are positive and significant at $1 \%$, reflecting the fact that the banks with greatest market power set highest margins. The result is compatible with that obtained by Maudos and Fernández de Guevara (2004) for the main European banking sectors.

The coefficients of operating costs are statistically significant (1\%), with the positive signs indicating that banks with high costs have to operate with higher intermediation margins to cover their higher operating costs. This result is consistent with that obtained by Brock and Rojas (2000), Martínez and Mody (2004), Gelos (2006) for Latin-American banks; Fernández de Guevara (2004) for Spanish banks; and Maudos and Fernández de Guevara (2004) for European banks.

\footnotetext{
${ }^{9}$ We eliminated from the sample any observations of doubtful reliability, and banks that did not report information for some of the variables necessary for estimating the indicators of competition. Because of these restrictions, the number of observations varies from a minimum of 13 in 1993 to a maximum of 32 in 1996.
} 
Table 1.

Sample descriptive statistics

\begin{tabular}{|c|c|c|c|c|c|c|c|c|c|c|c|c|c|c|c|c|c|}
\hline \multirow[b]{2}{*}{ Year } & \multirow[b]{2}{*}{ Banks } & \multirow[b]{2}{*}{ Statistics } & \multirow{2}{*}{$\begin{array}{c}\begin{array}{c}\text { Net interest } \\
\text { margin }\end{array} \\
\text { (Financial } \\
\text { income- } \\
\text { Financial } \\
\text { Expenses)/TA }\end{array}$} & \multirow{2}{*}{$\begin{array}{c}\begin{array}{c}\text { Market } \\
\text { power }\end{array} \\
\text { Lerner }^{1 /}\end{array}$} & \multirow{2}{*}{$\begin{array}{c}\begin{array}{c}\text { Operating } \\
\text { cost }\end{array} \\
\begin{array}{c}\text { Operating } \\
\text { cost/TA }\end{array}\end{array}$} & \multirow{2}{*}{$\begin{array}{c}\begin{array}{c}\text { Risk } \\
\text { aversion }\end{array} \\
\text { Equity/TA }\end{array}$} & \multirow{2}{*}{$\begin{array}{c}\begin{array}{c}\text { Interest rate } \\
\text { risk }\end{array} \\
\text { SD cetes } 91\end{array}$} & \multirow{2}{*}{$\begin{array}{c}\text { Credit risk } \\
\text { Loan loss } \\
\text { provision/loans }\end{array}$} & \multirow{2}{*}{$\begin{array}{c}\text { Size } \\
\ln \text { (loans) }\end{array}$} & \multirow{2}{*}{$\begin{array}{c}\text { Implicit } \\
\text { Interest } \\
\text { Payments }\end{array}$} & \multirow{2}{*}{$\begin{array}{c}\text { Opportunity } \\
\text { cost of } \\
\text { holding } \\
\text { reserves }\end{array}$} & \multirow{2}{*}{$\begin{array}{c}\begin{array}{c}\text { Quality of } \\
\text { management }\end{array} \\
\begin{array}{c}\text { Operating } \\
\text { cost/gross } \\
\text { income }\end{array}\end{array}$} & \multicolumn{2}{|c|}{ Specialization Variables } & \multirow{2}{*}{$\begin{array}{c}\begin{array}{c}\text { Fees and } \\
\text { commissions }\end{array} \\
\begin{array}{l}\text { Net fee } \\
\text { income }\end{array}\end{array}$} & \multirow{2}{*}{$\begin{array}{c}\begin{array}{c}\text { Trading } \\
\text { income }\end{array} \\
\begin{array}{c}\text { Net non } \\
\text { interest }\end{array} \\
\text { income - net } \\
\text { fee income }\end{array}$} & \multirow{2}{*}{\begin{tabular}{|c|c}
$\begin{array}{c}\text { Net non } \\
\text { interest } \\
\text { income }\end{array}$ \\
$\begin{array}{c}\text { Non interest } \\
\text { income-non } \\
\text { interest } \\
\text { expenses }\end{array}$
\end{tabular}} \\
\hline & & & & & & & & & & & & & Loans/TA & Deposits/TA & & & \\
\hline \multirow{2}{*}{1993} & \multirow[b]{2}{*}{13} & \multirow{2}{*}{$\begin{array}{c}\text { Mean } \\
\text { Standard } \\
\text { deviation } \\
\end{array}$} & 0.0550 & 0.0577 & 0.0408 & 0.0630 & 1.4117 & 0.0145 & 9.5647 & 0.3458 & 0.0253 & 0.6039 & 0.6188 & 0.5578 & 0.0043 & 0.0021 & 0.0158 \\
\hline & & & 0.0227 & 0.0759 & 0.0088 & 0.0311 & 0.0000 & 0.0113 & 1.1541 & 0.1244 & 0.0120 & 0.1201 & 0.1972 & 0.1401 & 0.0016 & 0.0081 & 0.0047 \\
\hline \multirow{2}{*}{1994} & \multirow{2}{*}{14} & \multirow{2}{*}{$\begin{array}{c}\text { Mean } \\
\text { Standard } \\
\text { deviation }\end{array}$} & 0.0434 & 0.0174 & 0.0354 & 0.0505 & 3.7207 & 0.0196 & 9.6768 & 0.4192 & 0.0244 & 0.6580 & 0.6244 & 0.5086 & 0.0036 & -0.0035 & 0.0130 \\
\hline & & & 0.0181 & 0.0869 & 0.0085 & 0.0156 & 0.0000 & 0.0096 & 1.2347 & 0.1960 & 0.0133 & 0.1403 & 0.1922 & 0.1205 & 0.0022 & 0.0111 & 0.0069 \\
\hline \multirow{2}{*}{1995} & \multirow[b]{2}{*}{24} & \multirow{2}{*}{$\begin{array}{c}\text { Mean } \\
\text { Standard } \\
\text { deviation }\end{array}$} & 0.0479 & -0.0232 & 0.0333 & 0.1095 & 20.5037 & 0.0249 & 7.9901 & 0.3762 & 0.0606 & 0.6835 & 0.5812 & 0.5385 & 0.0025 & -0.0044 & 0.0147 \\
\hline & & & 0.0383 & 0.0970 & 0.0096 & 0.0859 & 0.0000 & 0.0207 & 2.3172 & 0.6066 & 0.0933 & 0.5752 & 0.2412 & 0.1274 & 0.0042 & 0.0208 & 0.0136 \\
\hline & & Mean & 0.0321 & -0.0465 & 0.0342 & 0.1059 & 3.7212 & 0.0183 & 7.4647 & 0.4948 & 0.0556 & 0.8590 & 0.4857 & 0.4265 & 0.0028 & 0.0021 & 0.0156 \\
\hline 1996 & 32 & $\begin{array}{l}\text { Standard } \\
\text { deviation }\end{array}$ & 0.0220 & 0.1005 & 0.0132 & 0.0835 & 0.0000 & 0.0203 & 2.1999 & 0.6277 & 0.0938 & 0.5275 & 0.2344 & 0.2146 & 0.0031 & 0.0151 & 0.0128 \\
\hline & & Mean & 0.0544 & -0.0377 & 0.0593 & 0.1796 & 2.4620 & 0.0065 & 7.1787 & 0.9957 & 0.1164 & 1.2410 & 0.6660 & 0.5549 & 0.0063 & -0.0025 & 0.0085 \\
\hline 1997 & 31 & $\begin{array}{l}\text { Standard } \\
\text { deviation }\end{array}$ & 0.0312 & 0.1304 & 0.0365 & 0.1408 & 0.0000 & 0.0090 & 2.0816 & 1.8107 & 0.1003 & 1.6696 & 0.1754 & 0.1846 & 0.0057 & 0.0128 & 0.0143 \\
\hline & & Mean & 0.0551 & 0.0162 & 0.0538 & 0.1722 & 7.2513 & 0.0127 & 7.5621 & 0.9119 & 0.1433 & 1.1319 & 0.6771 & 0.5272 & 0.0065 & -0.0021 & 0.0128 \\
\hline 1998 & 24 & $\begin{array}{l}\text { Standard } \\
\text { deviation }\end{array}$ & 0.0335 & 0.1067 & 0.0425 & 0.1564 & 0.0000 & 0.0120 & 2.1589 & 2.2273 & 0.0989 & 1.8997 & 0.1795 & 0.2403 & 0.0063 & 0.0181 & 0.0173 \\
\hline 1090 & 25 & Mean & 0.0564 & 0.0452 & 0.0567 & 0.1567 & 2.9763 & 0.0206 & 7.3319 & 0.6089 & 0.2048 & 0.9852 & 0.6131 & 0.6556 & 0.0080 & 0.0026 & 0.0225 \\
\hline 1999 & 25 & $\begin{array}{l}\text { Standard } \\
\text { deviation }\end{array}$ & 0.0389 & 0.1077 & 0.0297 & 0.1209 & 0.0000 & 0.0243 & 2.0445 & 0.9323 & 0.1634 & 0.6947 & 0.2099 & 0.1867 & 0.0060 & 0.0241 & 0.0227 \\
\hline & & Mean & 0.0482 & 0.0457 & 0.0562 & 0.1710 & 1.5339 & 0.0136 & 7.1434 & 0.5255 & 0.1911 & 0.9313 & 0.5668 & 0.5481 & 0.0084 & 0.0040 & 0.0200 \\
\hline 2000 & 24 & $\begin{array}{l}\text { Standard } \\
\text { deviation }\end{array}$ & 0.0316 & 0.1012 & 0.0370 & 0.1095 & 0.0000 & 0.0190 & 2.1336 & 0.6988 & 0.1437 & 0.6347 & 0.2451 & 0.1904 & 0.0071 & 0.0155 & 0.0159 \\
\hline & & Mean & 0.0394 & 0.0678 & 0.0553 & 0.1324 & 2.9785 & 0.0183 & 7.2251 & 0.3015 & 0.2625 & 1.1933 & 0.5452 & 0.6613 & 0.0076 & 0.0065 & 0.0248 \\
\hline 2001 & 24 & $\begin{array}{l}\text { Standard } \\
\text { deviation }\end{array}$ & 0.0411 & 0.1036 & 0.0552 & 0.0914 & 0.0000 & 0.0175 & 2.4510 & 1.3488 & 0.2043 & 1.2909 & 0.2547 & 0.1860 & 0.0067 & 0.0208 & 0.0198 \\
\hline & & Mean & 0.0468 & 0.0666 & 0.0517 & 0.1608 & 0.7267 & 0.0296 & 7.5313 & 0.6495 & 0.1744 & 0.9488 & 0.5577 & 0.5892 & 0.0093 & 0.0009 & 0.0183 \\
\hline 2002 & 21 & $\begin{array}{l}\text { Standard } \\
\text { deviation }\end{array}$ & 0.0210 & 0.1123 & 0.0292 & 0.1328 & 0.0000 & 0.0777 & 2.4965 & 0.6466 & 0.0960 & 0.7458 & 0.2360 & 0.1973 & 0.0077 & 0.0171 & 0.0156 \\
\hline 2003 & 20 & Mean & 0.0424 & 0.0651 & 0.0397 & 0.1280 & 1.0487 & 0.0119 & 7.9353 & 0.4064 & 0.1580 & 0.7134 & 0.5947 & 0.5933 & 0.0103 & 0.0023 & 0.0191 \\
\hline 2003 & 20 & $\begin{array}{l}\text { Standard } \\
\text { deviation }\end{array}$ & 0.0166 & 0.0999 & 0.0144 & 0.0730 & 0.0000 & 0.0168 & 1.9250 & 0.2915 & 0.0633 & 0.2230 & 0.2119 & 0.2164 & 0.0080 & 0.0144 & 0.0124 \\
\hline & & & 0.0439 & 0.1323 & 0.0402 & 0.1165 & 0.7970 & 0.0091 & 7.9738 & 0.5032 & 0.1916 & 0.7713 & 0.5646 & 0.6132 & 0.0115 & 0.0004 & 0.0169 \\
\hline 2004 & 19 & $\begin{array}{l}\text { Standard } \\
\text { deviation }\end{array}$ & 0.0199 & 0.0750 & 0.0150 & 0.0548 & 0.0000 & 0.0082 & 1.8396 & 0.3426 & 0.1068 & 0.2918 & 0.2020 & 0.2196 & 0.0087 & 0.0054 & 0.0109 \\
\hline & & Mean & 0.0574 & 0.1587 & 0.0472 & 0.1467 & 0.4572 & 0.0088 & 7.8836 & 0.5436 & 0.2058 & 0.7028 & 0.5684 & 0.6014 & 0.0104 & 0.0009 & 0.0165 \\
\hline 2005 & 18 & $\begin{array}{l}\text { Standard } \\
\text { deviation }\end{array}$ & 0.0285 & 0.0660 & 0.0231 & 0.0921 & 0.0000 & 0.0091 & 2.0033 & 0.6956 & 0.1088 & 0.2906 & 0.2112 & 0.2102 & 0.0085 & 0.0117 & 0.0159 \\
\hline
\end{tabular}

${ }^{1 /}$ Weighted mean (Weight $=$ total assets)

Source: Own elaboration based on data from Comisión Nacional Bancaria y de Valores and Banco de México. 
Table 2.

Determinants of the net interest margin (Static model)

\begin{tabular}{|c|c|c|c|c|c|}
\hline Variable & (1) & ( 2 ) & (3) & (4) & ( 5 ) \\
\hline Lerner & $\begin{array}{c}0.1161 * \\
(9.29)\end{array}$ & $\begin{array}{c}0.1136 * \\
(9.01)\end{array}$ & $\begin{array}{c}0.1112 * \\
(8.24)\end{array}$ & $\begin{array}{c}0.1133 * \\
(8.98)\end{array}$ & $\begin{array}{l}0.1108 * \\
(8.19)\end{array}$ \\
\hline Operating Cost / total assets & $\begin{array}{c}0.3653 * \\
(5.82)\end{array}$ & $\begin{array}{c}0.3776 * \\
(5.67)\end{array}$ & $\begin{array}{c}0.3843 * \\
(5.20)\end{array}$ & $\begin{array}{c}0.3814 * \\
(5.18)\end{array}$ & $\begin{array}{c}0.3846 * \\
(4.8)\end{array}$ \\
\hline Equity / total assets & $\begin{array}{c}0.1098 * \\
(3.68)\end{array}$ & $\begin{array}{c}0.1049 * \\
(3.54)\end{array}$ & $\begin{array}{c}0.1098 * \\
(3.68)\end{array}$ & $\begin{array}{c}0.1017 * \\
(3.44)\end{array}$ & $\begin{array}{c}0.1074 * \\
(3.60)\end{array}$ \\
\hline SD91 & $\begin{array}{c}0.0006 * * \\
(2.4)\end{array}$ & $\begin{array}{l}0.0007 * * * \\
(2.70)\end{array}$ & $\begin{array}{l}0.0006 * * \\
(2.48)\end{array}$ & $\begin{array}{c}0.0007 * \\
(2.72)\end{array}$ & $\begin{array}{l}0.0006 * * \\
(2.51)\end{array}$ \\
\hline Loan loss provisions / loans & $\begin{array}{l}0.0794 * * \\
(2.11)\end{array}$ & $\begin{array}{l}0.0975 * * * \\
(2.62)\end{array}$ & $\begin{array}{r}0.0696 \\
(1.44) \\
\end{array}$ & $\begin{array}{c}0.1019 * \\
(2.79)\end{array}$ & $\begin{array}{r}0.0717 \\
(1.47) \\
\end{array}$ \\
\hline SD91*(non-performing loans/loans) & $\begin{array}{l}-0.0062 * * * \\
(-1.87)\end{array}$ & $\begin{array}{l}-0.0072 * * \\
(-2.23)\end{array}$ & $\begin{array}{l}-0.0081 * * \\
(-2.52)\end{array}$ & $\begin{array}{l}-0.0075 * * \\
(-2.33)\end{array}$ & $\begin{array}{l}-0.0083 * * \\
(-2.58)\end{array}$ \\
\hline Size & $\begin{array}{l}0.0041 * \\
(3.02)\end{array}$ & $\begin{array}{l}0.0047 * \\
(3.40)\end{array}$ & $\begin{array}{c}0.0044 * \\
(3.07)\end{array}$ & $\begin{array}{l}0.0045 * * \\
(2.17)\end{array}$ & $\begin{array}{l}0.0041 * * \\
(1.94)\end{array}$ \\
\hline Implicit Interest Payments & $\begin{array}{l}0.0028 * * \\
(2.04)\end{array}$ & $\begin{array}{l}0.0025 * * * \\
(1.92)\end{array}$ & $\begin{array}{l}0.0030 * * \\
(2.07)\end{array}$ & $\begin{array}{l}0.0025 * * * \\
(1.93)\end{array}$ & $\begin{array}{l}0.0029 * * \\
(2.07)\end{array}$ \\
\hline Liquid reserves / total assets & $\begin{array}{r}0.0006 \\
(0.06) \\
\end{array}$ & $\begin{array}{r}0.0031 \\
(0.26) \\
\end{array}$ & $\begin{array}{r}0.0059 \\
(0.47) \\
\end{array}$ & $\begin{array}{r}0.0079 \\
(0.56) \\
\end{array}$ & $\begin{array}{r}0.0093 \\
(0.65) \\
\end{array}$ \\
\hline Efficiency & $\begin{array}{c}-0.0042 * * \\
(-2.05)\end{array}$ & $\begin{array}{l}-0.0038 * * * \\
(-1.92)\end{array}$ & $\begin{array}{l}-0.0045 * * \\
(-2.07)\end{array}$ & $\begin{array}{l}-0.0037 * * * \\
(-1.94)\end{array}$ & $\begin{array}{l}-0.0045 * * \\
(-2.07)\end{array}$ \\
\hline Non-interest income & & $\begin{array}{l}-0.1776 * * * \\
(-1.75)\end{array}$ & & $\begin{array}{l}-0.1779 * * * \\
(-1.68)\end{array}$ & \\
\hline Fee & & & $\begin{array}{l}-0.4569 * * * \\
(-1.75)\end{array}$ & & $\begin{array}{l}-0.4459 * * * \\
(-1.67)\end{array}$ \\
\hline Trade & & & $\begin{array}{r}-0.1494 \\
(-1.41)\end{array}$ & & $\begin{array}{r}-0.1491 \\
(-1.38) \\
\end{array}$ \\
\hline Loans / total assets & & & & $\begin{array}{r}0.0052 \\
(0.58) \\
\end{array}$ & $\begin{array}{r}0.0040 \\
(0.46) \\
\end{array}$ \\
\hline Deposits / total assets & & & & $\begin{array}{r}-0.0062 \\
(-0.66)\end{array}$ & $\begin{array}{r}-0.0041 \\
(-0.45) \\
\end{array}$ \\
\hline N. obs. & 289 & 289 & 289 & 289 & 289 \\
\hline $\mathrm{R}^{2}$ & 0.883 & 0.887 & 0.889 & 0.888 & 0.889 \\
\hline Haussman test & 21.69 & 28.19 & 30.42 & 27.99 & 29.77 \\
\hline p-value & $(0.017)$ & $(0.003)$ & $(0.002)$ & $(0.009)$ & $(0.008)$ \\
\hline \multicolumn{6}{|c|}{ Elasticities } \\
\hline Lerner & $0.4915 *$ & $0.4809 *$ & $0.4708 *$ & $0.4795 *$ & $0.4692 *$ \\
\hline Operating Cost / total assets & $0.3631 *$ & $0.3753 *$ & $0.3820 *$ & $0.3790 *$ & $0.3822 *$ \\
\hline Equity / total assets & $0.3140 *$ & $0.3001 *$ & $0.3141 *$ & $0.2909 *$ & $0.3073 *$ \\
\hline SD91 & $0.0464 * *$ & $0.0497 *$ & $0.0425 * *$ & $0.0499 *$ & $0.0427 * *$ \\
\hline Loan loss provisions / loans & 0.0183 & $0.0230 * * *$ & 0.0123 & $0.0241 * * *$ & 0.0128 \\
\hline SD91*(non-performing loans/loans) & $0.1103 *$ & $0.1278 *$ & $0.0939 * *$ & $0.1312 *$ & $0.0957 * *$ \\
\hline Size & $0.0857 *$ & $0.0996 *$ & $0.0918 *$ & $0.0949 * * *$ & $0.0864 * *$ \\
\hline Implicit Interest Payments & $0.0180 * *$ & $0.0162 * * *$ & $0.0191 * *$ & $0.0158 * * *$ & $0.0188 * *$ \\
\hline Liquid reserves / total assets & 0.0019 & 0.0092 & 0.0178 & 0.0237 & 0.0279 \\
\hline Efficiency & $-0.0700 * *$ & $-0.0629 * * *$ & $-0.0744 * *$ & $-0.0617 * * *$ & $-0.0734 * *$ \\
\hline Non-interest income & & $-0.0626 * * *$ & & $-0.0627 * * *$ & \\
\hline Fee & & & $-0.0665 * * *$ & & $-0.0650 * * *$ \\
\hline Trade & & & -0.0023 & & -0.0023 \\
\hline Loans / total assets & & & & 0.0647 & 0.0499 \\
\hline Deposits / total assets & & & & -0.0736 & -0.0493 \\
\hline
\end{tabular}

Dependent variable: net interest income / total assets

Estimations with fixed effects

The reported t-statistics are based on robust standard errors

$\mathrm{t}$-statistics are in parentheses

* Significant at $1 \%$ ** significant at $5 \%$, and *** significant at $10 \%$

Source: Own elaboration based on data from Comisión Nacional Bancaria y de Valores and Banco de México. 
As, predicted by the theoretical model, positive and significant signs are obtained in the variables risk aversion, interest rate risk and credit rate risk, and we can observe that banks will set higher interest rates in order to obtain higher margins. However, credit risk is significant only in columns 1, 2 and 4. When we compare the results with other countries of Latin America, the positive sign of credit risk is consistent with that obtained by Brock and Rojas (2000) in the Colombian banking system but differs from the negative sign obtained by these same authors in the Argentine, Bolivian, Chilean and Peruvian systems ${ }^{10}$.

The interaction between the two risks is negative and significant, implying that the greater the volatility of interest rates and the greater the exposure to default risk, the less the effect on the interest margin. The negative sign may be explained by the result obtained by Brock and Rojas (2000) that non-performing loans are associated with smaller spreads in some countries of Latin America because of inadequate provisioning for loan losses. Another possible explanation given by the authors is that, on the assumption that banking authorities are reluctant to close banks in trouble and may encourage high risk, banks with a high proportion of bad loans may lower spreads as a way of trying to solve their problems. This latter explanation can be applied to the Mexican case given the unlimited deposit insurance (Fund for the Protection of Bank Savings, known by its Spanish acronym, FOBAPROA) which led the banks to incur high levels of credit risk, and thus aggravated the problems of moral hazard ${ }^{11}$.

Another determinant is the size of the transactions. The results show that banks with larger operations incur a high risk, and thus charge a higher margin. On the other hand, banking institutions with low implicit interest payments will set lower margins. In addition, the expected (negative) sign is obtained in the efficiency of banking management. Finally, the effect of with the opportunity cost of holding reserves is not statistically significant.

The introduction of the non-interest income variable has a negative and significant effect, showing that more diversified banks have lower intermediation margins; this may reflect a strategy of cross-subsidization with traditional activities (Carbó and Rodríguez, 2007; and Lepetit et al., 2008). Since banks engage in different non-lending activities, these other activities may influence the pricing of loan products

\footnotetext{
${ }^{10}$ Brock and Rojas (2000) proxy the credit risk variable with the ratio of non-performing loans to total loans.

${ }^{11}$ A detailed description of the rescue of the Mexican banking system can be found in Murillo (2002), Haber (2005), and Hernández (2007).
} 
due to cross-subsidization of bank products ${ }^{12}$. When the non-interest income variable is disaggregated into fee based activities and trading income, both present negative signs, although only the fee variable is significant.

With the aim of valuing the economic impact of the determinants of the intermediation margin, the bottom of table 2 shows the elasticities of the explanatory variables and their statistical significance. The most significant effects correspond to the market power, operating costs and risk aversion. The impact of the Lerner index is the most significant: when market power decreases by $10 \%$, ceteris paribus, the margin decreases between $4.7 \%$ and $4.9 \%$. The effect of average operating costs is also high; when this variable increases by $10 \%$, the margin increases between $3.6 \%$ and $3.8 \%$; and when risk aversion decreases by $10 \%$, the margin is reduced by between $2.9 \%$ and $3.1 \%$. The effect of the remaining variables is insignificant (see bottom of table 2).

Since the dependent variable analyzed (the intermediation margin) presents inertia in time because the banks need to match the random deposit supply function and the random demand of lending and non-traditional activities across periods, it is considered that the current values of the margins may be determined by their previous values (Carbó and Rodríguez, 2007). We therefore estimate the following dynamic model:

$$
M_{i t}=\xi M_{i t-1}+\sum_{j=1}^{J} \beta^{j} P S_{i t}^{j}+\sum_{k=1}^{K} \gamma^{k} B S_{i t}^{k}+\eta_{i}+v_{i t}
$$

where $\eta_{i}$ is an unobserved time-invariant bank-specific effect and $v_{i t}$ is a disturbance term. Given that the explanatory variables and the dependent variable are correlated with $\eta_{i}$, a transformation such as first-differencing is required to eliminate the individual effects.

For this purpose, we use the methodology proposed by Arellano and Bover (1995) and Blundell and Bond (1998), estimating a system of equations in both firstdifferences and levels (the "system" GMM estimator). The system GMM estimator thus combines the standard set of equations in first-differences with suitably lagged levels as instruments, and an additional set of equations in levels with suitably lagged firstdifferences as instruments. Two-step GMM estimators are used with asymptotic

\footnotetext{
${ }^{12}$ For example, banks may reduce lending rates to borrowers who also use bank services which generate fee and commission income, such as underwriting of securities.
} 
standard errors robust to heteroskedasticity (see table 3 ). In addition, and considering the small sample used, the two-step standard errors are computed in accordance to the Windmeijer (2005) finite-sample correction ${ }^{13}$. Furthermore, we consider the possibility that the explanatory variables are not strictly exogenous, such as the Lerner index and non interest income. Endogenity can arise, for instance, when causality is reversed, i.e., when the degree of market power or the importance of non-interest income depend on banking margins. If a bank operates with a low interest margin, it is possible that it tries to compensate for this low margin by an increase in non-interest income (such as fees and commissions). In the case of the Lerner index, because of the endogeneity of the cost and price variables, the variable is not exogenous. To address this potential endogeneity, we use lagged levels and lagged differences of the explanatory variables as instruments ${ }^{14}$.

In order to determine the consistency of the estimators, we verify the validity of the instruments and test lack of serial correlation (Arellano and Bond, 1991) by using the Hansen over-identifying test. No evidence is found to reject the null hypothesis that the model is correctly specified and the instruments are valid. In addition, to test the additional moment conditions used in the levels equation, the Hansen Difference statistic was used. According to this test, we accept their validity.

We use the statistic proposed by Arellano and Bond (1991) to test the absence of serial correlation of the errors in levels. This statistic tests the absence of second-order serial correlation of the first difference residuals. The evidence shows first-order serial correlation in differences (by construction) but no significant second-order serial correlation. Therefore, as Hansen's null hypotheses and the serial correlation tests are not rejected, the implementation of the dynamic model is validated.

\footnotetext{
${ }^{13}$ It is important to point out that there are two possible problems with the system GMM estimator. First, asymptotic standard errors of the efficient two-step GMM estimator can be severely downward biased in small samples. In order to avoid this problem, the Windmeijer correction (2005) is used. The inference of the results is robust if we estimate the dynamic model with the one-step GMM estimator. Hayakawa (2006) analyzes the small sample bias properties of the system GMM estimators in dynamic panel data models. He provides theoretical evidence as to why the system GMM estimator has smaller bias.Second, when the number of banks is low in comparison to the number of years overfitting biases can be present when using all the available moment conditions and the Sargan test may be weak. To avoid overfitting biases, instrument sets were restricted. For robustness, we estimate an alternative approach to the system GMM estimator for small samples, Least-Squares Dummy Variable (LSDV) estimator corrected for small simple bias (Kiviet, 1995; Bun and Kiviet, 2003 and Bruno 2005) and the system GMM results hold. These results are available upon request.

${ }^{14}$ As mentioned before, to avoid overfitting biases, we restrict the lag ranges used in generating these instrument sets and we collapse them (Roodman, 2009).
} 
Table 3.

Determinants of the net interest margin (Dynamic model)

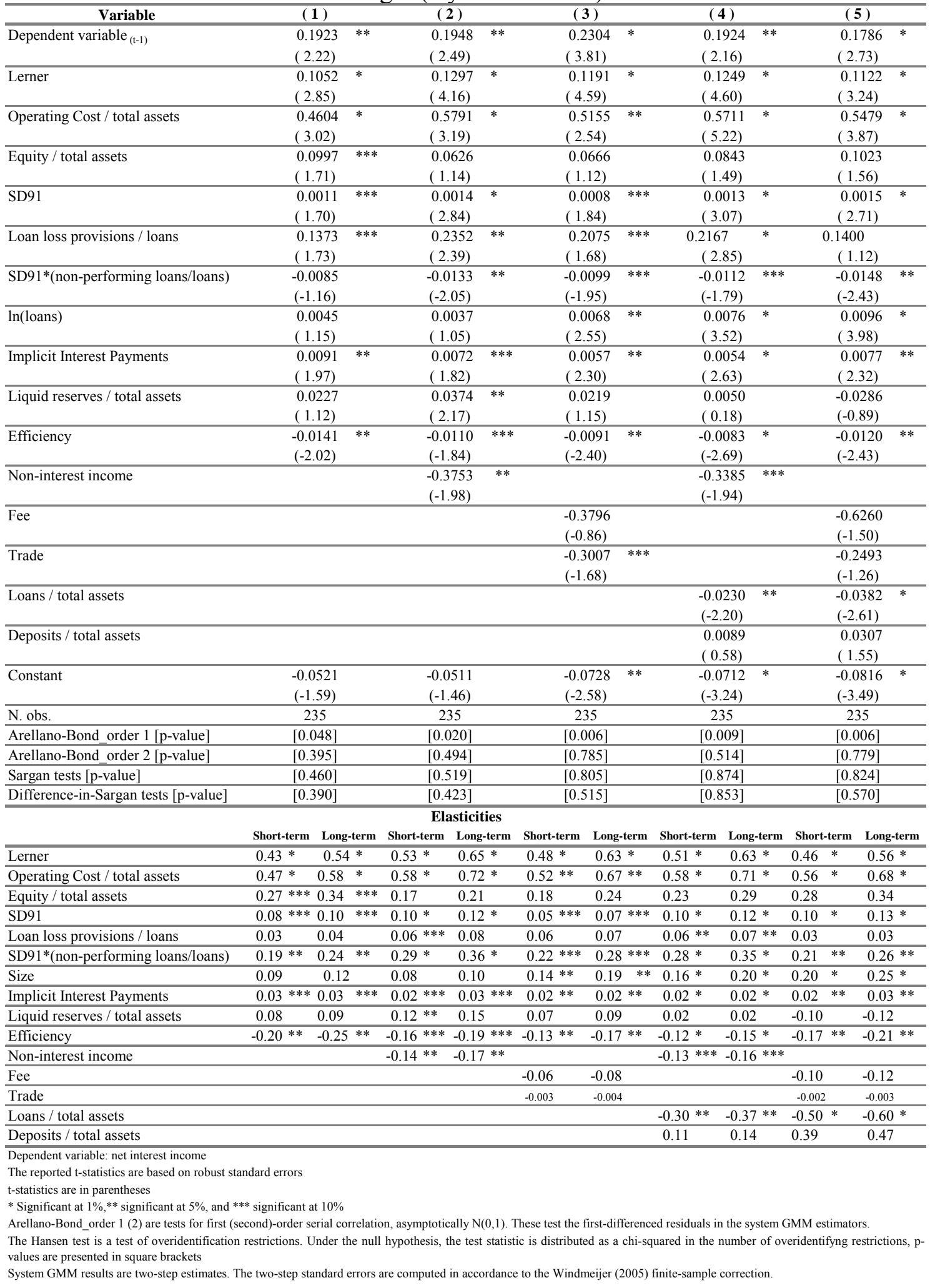

Difference-in-Sargan tests the additional instruments used by the System GMM estimator. Under the null hypothesis, valid specification, p-values are reported in square brackets. Source: Own elaboration based on data from Comisión Nacional Bancaria y de Valores and Banco de México. 
As was to be expected, inertia exists, and therefore the first order autoregressive component $\mathrm{AR}(1)$ is significant at $10 \%$ or less (see table 3 ). This indicates that a proper specification of the net interest margin must include an inertia term. In all cases, a positive and significant relation is maintained between the net interest margin and the variables market power, operating cost, market risk, and implicit interest payments. Risk aversion, credit risk and size have the expected sign but are not significant in all specifications.

Furthermore, there is a negative and significant relationship between the intermediation margin and efficiency in banking management. There is also a negative relationship between the dependent variable and the interaction between credit risk and interest risk (except column 1). Once again we find evidence that more diversified banks have lower intermediation margins. However, when non interest income is decomposed, we observe that trading income is significant only in column 3 .

Deposits/total assets does not significantly affect the interest margin. Finally, the significant negative sign of the coefficient of the specialization variable in the loans market may be explained by the result obtained by Maudos and Solís (2007) and Solís and Maudos (2008). That is to say, there is greater competitive rivalry in the loans market because there is cross-subsidization with deposits. Therefore, given there is greater competition in this sector, they set lower interest rates, ceteris paribus, and consequently a lower intermediation margin. Another possible explanation is that when banks specialize in the loans market, they reduce their intermediation costs thanks to the existence of economies of scale which translate into lower margins (columns 4 and 5 of table 3).

The elasticities in the dynamic model are likewise calculated. It is observed that the economic impact of the operating cost on the net interest margin is greater when we consider that the current values of the net interest margin are determined by its previous values. When the operating cost increases by $10 \%$, ceteris paribus, the margin increases between $4.7 \%(5.8 \%)$ and $5.8 \%(7.2 \%)$ in the short (long)-term. However, if the banks decrease the Lerner index by $10 \%$, their margins will decrease between $4.3 \%(5.4 \%)$ and $5.3 \%(6.5 \%)$ in the short (long)-term. The economic impact of the rest of the variables is analyzed in a similar manner (see bottom of table 3$)^{15}$.

\footnotetext{
${ }^{15}$ To test the robustness of the results, we estimate both the static and the dynamic models, using the differential between the interest rate on deposits and the inter-bank 28 day rate as proxy of market risk. The results are robust and are available upon request to the authors.
} 


\section{Conclusions}

In comparison to international standards, Mexico has high banking margins that reflect high intermediation costs. This has a negative effect on the growth of savings, investment, employment and, consequently, the country's economic growth. These reasons justify the importance of analyzing the determinants of intermediation margins in the Mexican banking system for the period 1993-2005,

The contributions of the paper in relation to other studies on the banking system are as follows. First, we develop theoretically a complete model that includes previous contributions by other authors, incorporating the original model by Ho and Saunders (1981), and average operating costs and non-traditional activities (Allen, 1988; Angbazo, 1997; Maudos and Fernández de Guevara, 2004; Carbó and Rodríguez, 2007). Second, the model is estimated empirically for the Mexican banking system for the first time. Moreover, following Carbó and Rodríguez (2007), we consider that the current values of the margins may be determined by their previous values, due to the existence of symmetric deposit, loan and non-traditional output arrival functions of the bank which may have different time patterns. Finally, we calculate the economic impact of the determinants on the net interest margin.

The results show that the most significant economic impact on the intermediation margin is determined by average operating costs and the Lerner index and the long-term elasticities are higher than those of short term. The results also show that, in general, we obtain the signs expected in the coefficients of the variables considered in the literature, explaining net interest income. Thus, we find evidence that the banks set higher intermediation margins if they enjoy greater market power. Furthermore, banking firms with high operating costs pass these on to their clients by setting higher rates of interest on credits and lower rates of interest on deposits, therefore leading to higher intermediation margins. The banks also protect themselves from a high volatility of market interest rates by charging higher net interest margins. In addition, we observe that banks that are not efficient in their management select less profitable assets and high-cost liabilities, leading to lower margins. Banks with high levels of implicit interest payment will set a higher margin because this variable represents an additional expense.

With regard to the diversification variable, we can conclude that, just as in more developed countries, non-interest income has increased during recent years and the sign of its coefficient shows that more diversified banks have lower intermediation margins, 
which may reflect a strategy of cross-subsidization with traditional activities (Carbó and Rodríguez, 2007; and Lepetit et al., 2008). This result suggests that well-developed fee income sources produces lower interest margins due to cross-subsidization of bank activities. The strengthened importance of fee-based (and other) income has affected the income structure of the Mexican banking system, increasing the weight of the noninterest income in total income (see figure 1). However, its economic impact is low, so the net interest margin has not decreased (unlike in developed countries), as the effect of market power and of average operating costs predominate, causing the margin to continue with high levels compared to international standards.

The model estimated serves to explain the evolution of net interest income in Mexico. The results obtained indicate that its evolution (which has not shown a downward trend as has occurred in developed countries) is consistent with that of average operating costs (except for 1995 and 2002) and the Lerner index (except for 1995 and 2000-01). (See figure 1). If we analyze its evolution in relation to the measures implemented in the Mexican banking system, we can observe that in the subperiod following the sale of the banks to the private sector (1993-94), the net interest margin decreases. This trend is provoked by the fall in market power and in operating costs. Subsequently, the exchange rate crisis had an adverse effect on inflation, and on interest rates and their volatility. Credit risk and risk aversion have also been affected, causing an increase in the net interest margin. However, this increase is not as significant because it is counteracted by the decrease in market power. In the sub-period of restructuring and starting the consolidation of the Mexican banking system (199699), the net interest margin increased as a consequence of the increase in the Lerner index and in average operating costs. However, the margin decreased from 2000 to 2003. This effect is explained by the fall of 2000 and 2001 (2002 and 2003) in average operating costs (slight fall in market power), credit risk, implicit interest payments counteracting the increase in market power (average operating costs). Finally, at the end of the period analyzed (2004-05), we observe a tendency for the interest margin to increase (as the Banco de México (2008) assets. This tendency is due to growth of the credit granted to the private sector, particularly to households and SMEs, and the bancarization process that rearch segment of the population with more risk), propitiated by a context of rising interest rates and also by an increase in market power ${ }^{16}$.

\footnotetext{
${ }^{16}$ Solís and Maudos (2008) show that since 1998, and with great intensity in 2004 and 2005, the market has increased substantially, tripling its value to reach the highest level in 2005. In parallel, the levels of profitability (ROA) of the Mexican banking sector have increased substantially since 1998, especially in 2004 a 2005. In the same period, there has been an increase in the market concentration (CR3).
} 


\section{Figure 1. Evolution of the net interest margin and its determinants ${ }^{17}$}

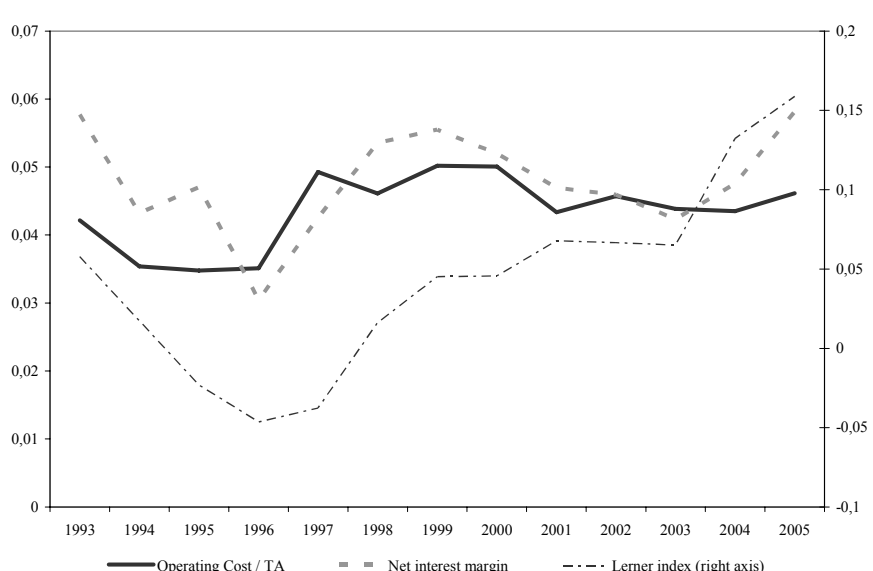

Source: Own elaboration based on data from Comisión Nacional Bancaria y de Valores and Banco de México.

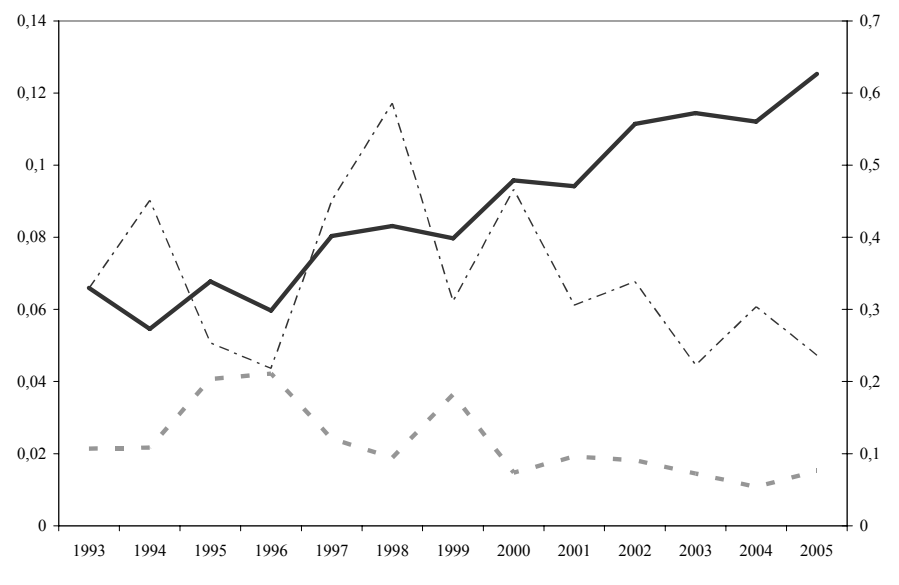

Source: Own elaboration based on data from Comisión Nacional Bancaria y de Valores and Banco de México.

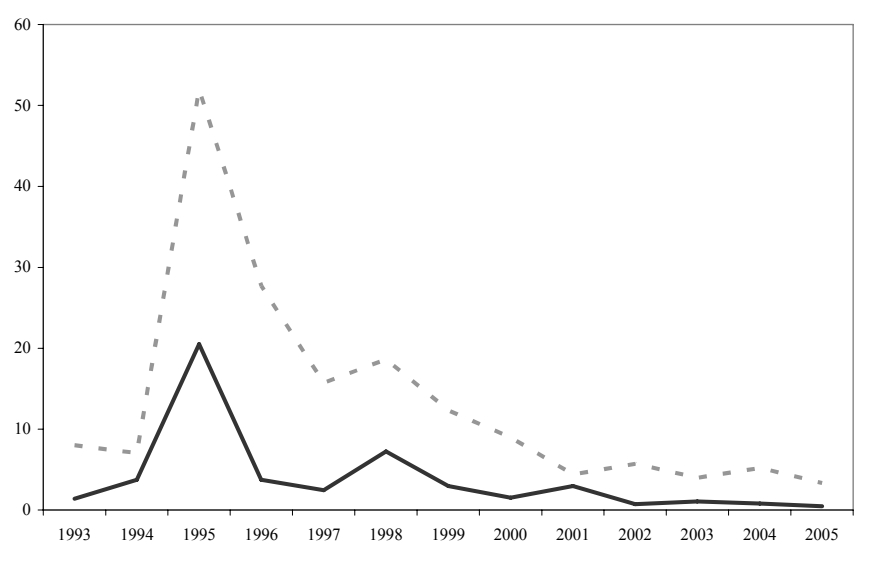

- Interess rate risk $=-$ Inflation rate

Source: Own elaboration based on data from Comisión Nacional Bancaria y de Valores and Banco de México and INEGI.

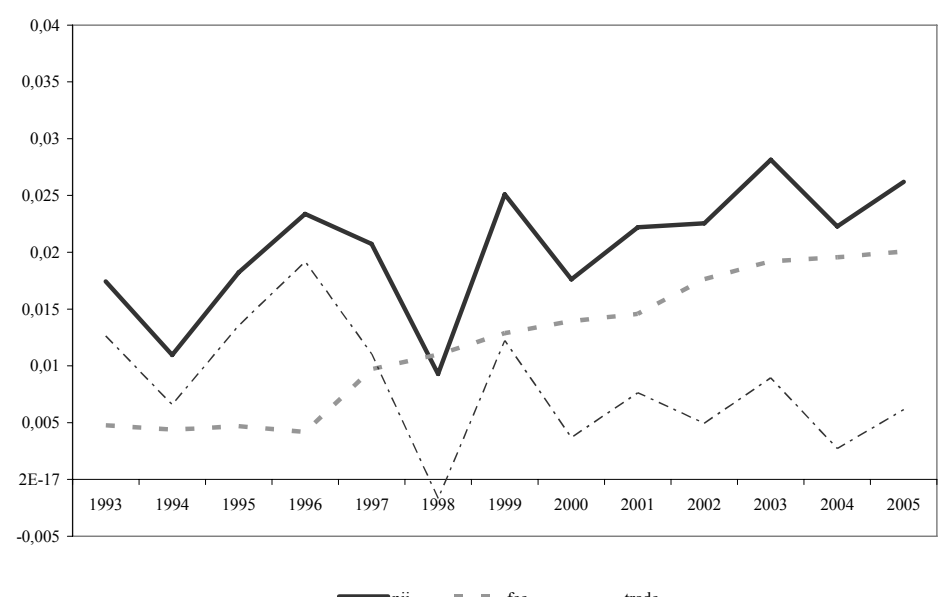

Source: Own elaboration based on data from Comisión Nacional Bancaria y de Valores.

${ }^{17}$ Indicators for the totality of the commercial banks reported by the CNBV, except for the Lerner index which is estimated from sample data. 
From an economic policy orientation, the results obtained permit us to conclude that policies should be aimed at increasing competition and promoting efficiency in the banking sector, and at favoring stable macroeconomic conditions. In terms of competition, the evidence contributed by other works (along with the complaints made by a group of senators urging the Bank of Mexico to regulate the maximum interest rate banks should be allowed to charge) show that monopolistic practices exist in some important markets. It is therefore necessary to prioritize measures aimed at increasing competition (such as decreasing the legal barriers to some products and fostering coordination between anti-trust authorities and regulators). Regarding efficiency, it is important that the Mexican banking system reduces its costs, which lower margins and benefit consumers. Finally, in the current international financial crisis, results from the study allow us to shed light on some of the possible effects on banking margins. The Mexican banking system is one of the sectors of the economy which has most suffered because of the successive crises that the country has gone through over the years (such as in 1995). The current deterioration of macroeconomic conditions with the consequent increase in bad loans can pressure bank margins to rise caused by the greater risk premiums that will banks demand. 


\section{Appendix}

Banks are maximizers of their expected utility of their wealth $(W)$ and their utility function is proxied using the Taylor expansion around $E\left(W_{T}\right)=\bar{W}$. Thus, the change in the expected utility after a transaction $Q$-a new deposit $(Q=D)$, loan $(Q=L)$ or non-traditional output $(Q=N)$ - is given by:

$$
\begin{aligned}
E U(\Delta W \mid Q=D) & =U^{\prime}(\bar{W})(a Q-C(D))+\frac{1}{2} U^{\prime \prime}(\bar{W})\left[(a Q-C(D))^{2}+\left(Q+2 M_{0}\right) Q \sigma_{M}^{2}\right. \\
& \left.+\left(Q-2 I_{0}\right) Q \sigma_{I}^{2}+2 I_{0} Q \sigma_{I M}\right] \\
E U(\Delta W \mid Q=L) & =U^{\prime}(\bar{W})\left(b_{L} Q-C(L)\right)+\frac{1}{2} U^{\prime \prime}(\bar{W})\left[\left(b_{L} Q-C(L)\right)^{2}+\left(Q-2 M_{0}\right) Q \sigma_{M}^{2}\right. \\
+ & \left.\left(Q+2 I_{0}\right) Q \sigma_{I}^{2}+2\left(M_{0}-I_{0}-Q\right) Q \sigma_{I M}\right] \\
E U(\Delta W \mid Q=N) & =U^{\prime}(\bar{W})\left(b_{N} Q-C(N)\right)+\frac{1}{2} U^{\prime \prime}(\bar{W})\left[\left(b_{N} Q-C(N)\right)^{2}+\left(Q-2 M_{0}\right) Q \sigma_{M}^{2}\right. \\
+ & \left.\left(Q+2 I_{0}\right) Q \sigma_{I}^{2}+2\left(M_{0}-I_{0}-Q\right) Q \sigma_{I M}\right]
\end{aligned}
$$

where it is assumed that the bank's utility function is continuous doubly differentiable with $\mathrm{U}^{\prime}>0$ and $\mathrm{U}^{\prime}<0$, i.e. the bank is risk averse.

Given the probabilities $\lambda$ of receiving a deposit, granting a loan and selling a nontraditional output (Ho and Saunders, 1981; Allen, 1988; Carbó and Rodríguez, 2007), the bank seeks to maximize the expected utility of its wealth:

$$
\underset{a, b_{L}, b_{N}}{\operatorname{Max}} E U(\Delta \tilde{W})=\lambda(a)(A .1)+\lambda\left(b_{L}\right)(A .2)+\lambda\left(b_{N}\right)(A .3)
$$

Solving for the different bank fees, the first order conditions yield the following expressions of the immediacy fees: ${ }^{17}$

$$
\begin{aligned}
& a=\frac{1}{2} \frac{\alpha_{D}}{\beta_{D}}+\frac{C(D)}{2 Q}+\frac{R}{4}\left[\left(Q-2 I_{0}\right) \sigma_{I}^{2}+\left(Q+2 M_{0}\right) \sigma_{M}^{2}+2\left(I_{0}-M_{0}-Q\right) \sigma_{I M}\right] \\
& b_{L}=\frac{1}{2} \frac{\alpha_{L}}{\beta_{L}}+\frac{C(L)}{2 Q}+\frac{R}{4} Y+\frac{\delta_{L}}{4 \beta_{L}}\left\{2 b_{N}\left(1+\frac{\delta_{N}}{\delta_{L}}\right)-R Y-\frac{2 C(N)}{Q}\right\}
\end{aligned}
$$

\footnotetext{
${ }^{17}$ As in Ho and Saunders (1981), the second order immediacy fees are assumed to be negligible.
} 
$b_{N}=\frac{1}{2} \frac{\alpha_{N}}{\beta_{N}}+\frac{C(N)}{2 Q}+\frac{R}{4} Y+\frac{\delta_{N}}{4 \beta_{N}}\left\{2 b_{L}\left(\frac{\delta_{L}}{\delta_{N}}+1\right)-R Y-\frac{2 C(L)}{Q}\right\}$

where:

$Y=\left(Q+2 I_{0}\right) \sigma_{I}^{2}+\left(Q-2 M_{0}\right) \sigma_{M}^{2}+2\left(M_{0}-I_{0}-Q\right) \sigma_{I M}$

$R \equiv-U^{\prime \prime} / U^{\prime}$ is the coefficient of absolute risk aversion

The optimal interest margin $a+b_{L}$ is given by expression (1), and the optimal gross margin $a+b_{L}+b_{N}$ by expression (2). 


\section{REFERENCES}

Allen, L., 1988. The determinants of bank interest margins: A note. Journal of Financial and Quantitative Analysis 23 (2), 231-235.

Avalos, M. and Hernández-Trillo, F., 2006. Competencia bancaria en México. Serie estudios y perspectivas 62. CEPAL, Publicación de Naciones Unidas: Mexico City.

Angbazo, L., 1997. Commercial bank net interest margins, default risk, interest-rate risk and off-balance sheet banking. Journal of Banking and Finance 21, 55-87.

Arellano, M., Bond, R.M., 1991. Some test of specification for panel data: Monte Carlo evidence and application to employment equations. Review of Economics Studies 58 (2), 277-297.

Arellano, M., Bover, O., 1995. Another Look at the Instrumental-Variable Estimation of Error-Components Models. Journal of Econometrics 68, 29-52.

Banco de México, 2007. Reporte sobre el sistema financiero 2006. Banco de México: Mexico City.

Banco de México, 2008. Reporte sobre el sistema financiero 2007. Banco de México: Mexico City.

Blundell, R.W., Bond, S.R., 1998. Initial conditions and moment restrictions in dynamic panel data models. Journal of Econometrics 87, 115-143.

Brock, P., Rojas, L., 2000. Understanding the behavior of bank spreads in Latin America. Journal of Development Economics 63, 113-134.

Bun, M.J.G., Kiviet, J.F., 2003. On the diminishing returns of higher order terms in asymptotic expansions of bias. Economics Letters 79, 145-152.

Bruno, G.S.F., 2005. Approximating the bias of the LSDV estimator for dynamic unbalanced panel data models. Economics Letters 87, 361-366.

Carbó, S., Rodríguez, F., 2007. The determinants of bank margins in European banking. Journal of Banking \& Finance 31, 2043-2063.

Claeys, S., Vander Vennet, R., 2008. Determinants of bank interest margins in Central and Eastern Europe: A comparison with the West. Economic Systems 32(2), 197-216. 
Comisión Nacional Bancaria y de Valores, several years. Boletín Estadístico de Banca Múltiple. Comisión Nacional Bancaria y de Valores: Mexico City.

Demirgüç-Kunt, A., Huizinga, H., 1999. Determinants of commercial bank interest margins and profitability: Some international evidence. World Bank Economic Review 13, 379-408.

Drakos, K., 2002. The Dealership model for interest margins: The case of the Greek banking industry. Journal of Emerging Market Finance 1, 75-98.

Fernández de Guevara, J., 2004. Evolución del margen de intermediación en España: ¿Tipos de interés, riesgo costes o competencia? Revista de Economía Financiera 2, 4-27.

Gelos, R., 2006. Banking spreads in Latin America. IMF Working Paper WP/06/44. International Money Fund: Washington.

Haber, S., 2005. Mexico's experiments with bank privatization and liberalization, 19912003. Journal of Banking and Finance 29, 2325-2353.

Hayakawa, K., 2006. Small sample bias properties of the system GMM estimator in dynamic panel data models. Economics Letters 95, 32-38.

Hernández-Murillo, R., 2007. Experiments in Financial Liberalization: The Mexican Banking Sector. Federal Reserve Bank of St. Louis Review 89 (5), 415-432.

Ho, T., Saunders, A., 1981. The determinants of banks interest margins: Theory and empirical evidence. Journal of Financial and Quantitative Analysis XVI (4), $581-600$.

Kiviet, J.F., 1995. On bias, inconsistency and efficiency of various estimators in dynamic panel data models. Journal of Econometrics 68, 53-78.

Lepetit, L., Nys, E., Rous, P., Tarazi, A., 2008. The expansion of services in European banking: Implications for loan pricing and interest margins. Journal of Banking \& Finance 32 (11), 2325-2335.

Martínez, M.S., Mody, A., 2004. How foreign participation and market concentration impact bank spreads: evidence from Latin America. Journal of Money, Credit and Banking 36 (3), 511-537.

Maudos, J. Fernández de Guevara, J., 2004. Factors explaining the interest margin in the banking sectors of the European Union. Journal of Banking \& Finance 28, 22592281 
Maudos, J. and Solís, L., 2007. Deregulation, liberalization and consolidation of the Mexican banking system: effects on competition. Working Paper WP-EC 200713. Instituto Valenciano de Investigaciones Económicas: Valencia.

Mc Shane, R.W., Sharpe, I.G., 1985. A time series/cross section analysis of the determinants of Australian Trading bank loan/deposit interest margins: 19621981. Journal of Banking \& Finance 9, 115-136.

Murillo, J., 2002. La banca en México: privatización, crisis y reordenamiento. Working Paper, Banco de México: Mexico City.

Roodman, D., 2009. A Note on the Theme of Too Many Instruments. Oxford Bulletin of Economics and Statistics 71 (1), 135-158.

Saunders, A., Schumacher, L., 2000. The determinants of bank interest rate margins: An international study. Journal of International Money and Finance 19, 813-832.

Solís, L. and Maudos, J., 2008. The social costs of bank market power: evidence from Mexico. Journal of Comparative Economics 36 (3), 467-488.

Windmeijer, F., 2005. A finite sample correction for the variance of linear efficient twostep GMM estimators. Journal of Econometrics 126(1), 25-51. 


\section{PUBLISHED ISSUES ${ }^{*}$}

WP-EC 2009-01 "The effects of immigration on the productive structure of Spanish Regions"

J. Martín, G. Serrano, F. Requena. February 2009.

WP-EC 2009-02 "Corporate governance and impression management in annual press releases"

B. García, E. Guillamón-Saorín. March 2009.

WP-EC 2009-03 "Factores determinantes de la salida a bolsa en España" J.E. Farinós, V. Sanchis. April 2009.

WP-EC 2009-04 "New challenges in competitiveness: knowledge development and coopetition"

C. Camisón-Zornoza, M. Boronat-Navarro, A. VillarLópez. April 2009.

WP-EC 2009-05 "The determinants of net interest income in the Mexican banking system: an integrated model"

J. Maudos, L. Solís. April 2009.

WP-EC 2009-06 "Explaining protectionism support: the role of economic factors"

N. Melgar, J. Milgram-Baleix, M. Rossi. April 2009.

* Please contact Ivie's Publications Department to obtain a list of publications previous to 2009. 


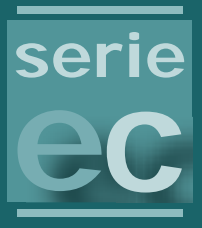

\section{I vie}

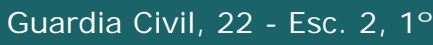
46020 Valencia - Spain

Phone: +34963190050

Fax: +34 963190055

Website: http:/ / www.ivie.es

E-mail: publicaciones@ivie.es 